\title{
Community, Communion, and Communism: Religion and Spirituality in Herbert Read's Anarchism
}

Matthew S. Adams

Loughborough University, UK

Herbert Read was not a religious anarchist, but nevertheless a sense of the spiritual played an important role in his thought. Through a comparison with the work of H.G. Wells, who Read treated as a representative of a particularly arid form of social theory, this chapter reconstructs Read's argument that spiritual unity was integral to any functioning society, and would therefore also be important to any successful anarchist community. The truth of the lesson was revealed for Read in the centrality of spiritual vibrancy to historical moments of particular artistic creativity. With cultural effervescence his measure of the successful realisation of meaningful freedom, he theorised a utopian anarchist community defined by both its economic communism and spiritual communion.

Even though he was no particular fan of H.G. Wells' writing, Herbert Read admitted, perhaps mainly out of politeness, to enjoying the "fantasia about dreams called The Happy Turning" that Wells was "circulating among a few friends" in the summer of I943. ${ }^{\text {I }}$ However, Read informed Wells, while he agreed with the "underlying moral" of the story, he confessed that he "jibbed

${ }^{\text {I }}$ H.G. Wells to Herbert Read: $13^{\text {th }}$ July 1943 ", Herbert Read Papers, McPherson Library, University of Victoria. [Hereafter: HRP] HR/HGW7 Eud.04.

How to cite this book chapter:

Adams, M. S 2020. Community, Communion, and Communism: Religion and Spirituality in Herbert Read's Anarchism. In: Christoyannopoulos, A. and Adams, M. S. (eds.) Essays in Anarchism and Religion: Volume III. Pp. II9-I 50. Stockholm: Stockholm University Press. DOI: https://doi. org/IO.I 6993/bbb.d. License: CC-BY 
at $[\ldots]$ one aspect", which was "its out of date anti-clericalism." Lest he be misinterpreted, this was not, Read added, out of any attachment to "priests or churches", but instead reflected the simple fact that organised religion exercised little power in mid-century Britain. In countries "like" Spain religion might play an influential role, but in Britain as "in most parts of the world [churches and priests] seem to me to be as harmless as the rats and crows which [...] inhabit their historic monuments." 3

Read's letter to Wells suggests that he unequivocally saw religion as an irrelevance in the modern world, yet his comments do not convey the underlying complexity of his position. While demonstrating his hostility to the rituals, conventions, and hierarchies of the Church, more broadly Read actually held a generally ambiguous, and frequently magnanimous, view of religion and spirituality, seeing religion as an important, often vital, cohesive force throughout human history. But religious feeling was not something that he simply saw as an historically useful phenomenon. When pondering the shape of an anarchist future unencumbered by capitalism and the state, Read often noted the importance of shared spiritual values in ensuring the survival of any experiment in anarchy. Anarchism was for Read a rational project - the soundest basis upon which to found a just and free society - but he was at the same time a critic of the kind of arid rationalism that he thought characterised social scientific thinking in the mid-twentieth century. Anarchism's rational ideal must also be in tune with, and draw upon, the spiritual values beating in the heart of any viable community, he concluded.

Read's perspective on religion therefore offers an interesting via media in debates about the possible compatibility of religious and anarchist thought, from an intellectual who enjoyed a complex relationship with anarchism as a political tradition. Most famous in his lifetime as a propagandist for modernist art, ${ }^{4}$ Read always

${ }^{2}$ Herbert Read to H.G. Wells: $27^{\text {th }}$ August, I943 in HRP: HR/HGW9 Eud.04. For Read's comments on Wells, see: Herbert Read, The Contrary Experience: Autobiographies (London: Faber and Faber, I963), pp. 88-89.

3 Read to Wells: $27^{\text {th }}$ August, I943.

4 For the definitive biography of Read, see James King, The Last Modern: A Life of Herbert Read (New York: St. Martin's Press, I990). 
pointed to the 'unity' of his diverse interests - which included literary criticism, the philosophy of art, psychoanalysis, and art education - with anarchism a key connecting thread. 'There is no separation', he wrote in I954, 'between what I have written on this subject [anarchism] and what I have written on social problems generally...on the social aspects of art...or on the social aspects of education. The same philosophy reappears in my literary criticism and in my poetry'. ${ }^{5}$ The intellectual restlessness that characterised his life, and his imperfect efforts to think about the consequences of his defence of the numinous, mysterious, and individual impulses underpinning artistic creativity for the rational and collectively-minded political ideology he subscribed to, mean that his ideas offer a useful route into thinking about anarchism's relation to the spiritual. While this debate has often centred upon the legitimacy of deistic thinking in the context of a political tradition defined by its rejection of authority, Read's theorisation of necessary spirituality offers a different take on this conundrum. ${ }^{6} \mathrm{He}$ was not a 'Christian anarchist' in the sense of the intellectual position outlined by Alexandre Christoyannopoulos, where an 'explicitly "anarchist" conclusion' is reached "based on [an] understanding of "Christianity" ", even if he has been thought of in these terms." Nicolas Walter, for example, admittedly no fan of Read whom he considered dilettantish and politically shallow, judged that he saw anarchism as an essentially "religious philosophy". ${ }^{8}$ Walter overstated the case, but Read certainly did see connections between the religious impulse and communalist ethics that an anarchist community might usefully approximate. This sense of the importance

5 Herbert Read to Francis Berry: I $^{\text {th }}$ April I953, HRP, 6I/20/9; Herbert Read, Anarchy and Order: Essays in Politics (London: Faber \& Faber, I954), p. 9.

${ }^{6}$ For an overview see Alexandre Christoyannopoulos and Lara Apps, 'Anarchism and Religion' in Carl Levy \& Matthew S. Adams (eds.) The Palgrave Handbook of Anarchism (Basingstoke: Palgrave, 20I9), pp. I69-I92 (especially pp. I70-I76).

7 Alexandre J.M.E. Christoyannopoulos, Christian Anarchism: A Political Commentary on the Gospel (Exeter: Imprint Academic, 2010), p. 269.

8 Nicolas Walter, "Anarchism and Religion" in Damned Fools in Utopia, ed. David Goodway (Oakland, CA: PM Press, 2009), pp. 279-285 (p. 284). 
of spiritual unity also found expression in Read's broader concern with the social status of the arts, and the idea, explored in his historical studies, that those societies with the strongest communal ethic achieved the most vibrant art. ${ }^{9}$

To consider Read in terms of the "spiritual" also highlights the ambiguity of that concept. If, in comparing the slippery category of "spirituality" with the equally ineffable "religion", we characterise the former as exemplified by a quest for an "authentic connection with the inner depths of one's unique life-in-relation", and the latter as an impulse to "conformity to external authority", we begin to see how an anarchist may conceivably approach the spiritual as a component of social liberation. ${ }^{\text {IO }}$ Inevitably, however, such neat distinctions fail to support the interpretative weight they must bear. After all, popular, but less precise uses of "spiritual" often point to a blending of these perspectives:

'Spirituality' is often used in Christian circles to express devotion to God [...] as when spirituality is thought of as 'obedience to the will of God' with the believer entering into an intense relationship (involving surrender) with the divine. Such spirituality is subjective

9 While there is a tendency to bifurcate his cultural and political ideas, Read was in fact mirroring ideas adumbrated by Kropotkin, who similarly saw a defining relationship between great art and communal unity. In contrast to Kropotkin, Read's articulation of this idea was a prominent feature of his thought, revealing a theme that has a deeper place in the history of anarchist political thought, but has often been implicit. On the division between Read's aesthetics and politics, consider the work of David Goodway and Peter Marshall, who, while recognising that Read saw a fundamental connection, are sceptical. David Goodway, Anarchist Seeds Beneath the Snow: Left-Libertarian Thought and British Writers from William Morris to Colin Ward (Liverpool: Liverpool University Press, 2006), p. I 8I, I84; David Goodway, "Herbert Read, organicism, abstraction and an anarchist aesthetic" in Anarchist Studies, Vol. I9, No. I (200I), pp. 82-97; Peter Marshall, Demanding the Impossible: A History of Anarchism (London: Fontana, 1993), p. 592. For this narrative in Kropotkin's work, see: Peter Kropotkin, The Conquest of Bread (New York: G.P. Putman's Sons, I907), pp. I24-I43. For a more detailed exploration, see: Matthew S. Adams, Kropotkin, Read, and the Intellectual History of British Anarchism: Between Reason and Romanticism (Basingstoke: Palgrave, 2015).

ro Paul Heelas and Linda Woodhead, The Spiritual Revolution: Why Religion is Giving Way to Spirituality (Oxford: Blackwell, 2005), p. 4. 
in the sense that it involves often intense experiences...but objective in the sense that it is focused on something which [...] remains external to and higher than the self. ${ }^{\text {II }}$

We should not expect Read to bring clarity to the concept of spirituality, but this chapter demonstrates that a sense of the spiritual that cuts across these definitions plays an important role in his utopian politics. Purged of any sense of obedience to God, his utopianism does, nevertheless, place importance on a social unity informed by an intense, authentic, relationship between individuals, and, in his writing on art, a surrender to something beyond individual experience that highlights a sense of the numinous running through his thought. Given that Read's anarchism drew most directly on the work of Peter Kropotkin - a figure often encountered as an unforgivingly deterministic and mechanically-minded thinker - this interest in the spiritual points to a distinctive thread in Read's philosophy, and one that reflects a willingness to draw insights from otherwise distinct philosophical approaches, including the individualism of Max Stirner and Carl Jung's psychoanalysis. ${ }^{\text {I2 }}$

Having established his sympathetic interpretation of spirituality, and, in the second section of this chapter, traced its prominence in his thought in relation to his hope for a revivified culture, the final section considers Read's position in the wider intellectual history of the period. Juxtaposing his defence of spirituality with Wells' critique of religion reveals the generational gap between these thinkers, one that it is possible to map onto the complex cultural legacies of the First World War. His congeniality to spiritualism, and his predilection for romanticism, demonstrates the inappropriateness of overstating the case for seeing the war as a "slaughterhouse" for Edwardian verities. ${ }^{13}$ Rather than a brave new world, modernism, and post-war British culture more generally, often felt a renewed acquaintance with tradition.

ir Ibid., p. 5 .

${ }^{12}$ For more on Read's approach to Stirner and Jung, see: Adams, Kropotkin, Read, and the Intellectual History of British Anarchism, pp. I75-I 79.

I3 Modris Eksteins, Rites of Spring: The Great War and the Birth of the Modern Age (New York, I989), p. 258. 


\section{I. "The needle between reason and romanticism": utopianism, community, and the spiritual}

Wells' The Happy Turning: A Dream of Life, published in 1945 and written in the heat of the Second World War, charts the author's attempts to escape the "overstrain" occasioned by the present "chaotic war", in the comfort of sleep. "More and more", he writes, "are my dreams what I believe the psychologists call compensatory; the imaginations I have suppressed revolt and take control.” I4 An early reference to J.W. Dunne's influential work An Experiment with Time (I927) points to the text's affinities with one of Wells' more famous forays into genre-blending fiction, The Shape of Things to Come. Published in 1933 and presenting itself as a "Short History of the World for about the next century", in this text Wells occupies the role of editor and literary executor to the fictional historian Dr Philip Raven. ${ }^{15}$ Inheriting Raven's notes upon his untimely death, Wells writes that he compiled the "dream book" from these scattered manuscripts, revealing an imaginative attempt to record the history of the future. In his introduction, Wells recounts Raven's belief in the argument put forward in An Experiment with Time that "we may anticipate the future" and that "in the dozing moment between wakefulness and oblivion" some intimation of future events is possible. ${ }^{16}$ For the real-life Dunne, this was a prelude to highlighting the role of human consciousness in ordering time, a hardwiring escaped in sleep, during which precognitive dreams reveal that all states of time are, in fact, simultaneous. ${ }^{17}$

The dream state had long been a favoured method for utopian writers to imagine the contours of a possible future. Unencumbered by either the restrictions of an imagination-confining present, or the difficulty of inventing a feasible plot device that enables the present to be juxtaposed with the utopian future, the dream state

\footnotetext{
${ }^{14}$ H.G. Wells, The Happy Turning: A Dream of Life (London: William Heinemann, I945), p. I, 7.

is H.G. Wells, The Shape of Things to Come (London: Gollancz, [1933] 2OII), p. 4 .

${ }^{16}$ Wells, The Shape of Things to Come, p. 7.

${ }_{17}$ J.W. Dunne, An Experiment with Time (London: A. \& C. Black, I929), pp. 29-38, 23-I 25 .
} 
allows the utopian writer to move between reality and fancy at will, mining the unwritten future for lessons of immediate political salience. Often, as in William Morris' News from Nowhere (I 890), these slumbering visions were imbued with an appropriately romantic imagery, in this example a product of Morris' indebtedness to the late-Victorian cult of the medieval that was an antidote to the smokestacks and riveted-iron of nineteenth-century capitalism. ${ }^{18}$ Wells' oscitant premonitions, as his use of Dunne's pseudoscientific theories indicate, were rather different however, rooting themselves in the voguish language and concepts of contemporary sociology. Manifesting a "degree of institutional specificity" that stood in distinction to Morris' playfulness, Wells also tended to present his utopian speculations - despite their often-fantastical settings - in terms of their eminent plausibility. ${ }^{19}$ A common theme in these works, such as Anticipations (I90I) and A Modern Utopia (1905), was the importance of enlightened minorities acting under the aegis of a powerful state replacing the anarchy of the present with a technologically sophisticated and orderly society, a vision echoed in The Shape of Things to Come. ${ }^{20}$

Wells' utopianism is an important context for comprehending both Read's location in deeper traditions of British radicalism and utopian speculation, and his general antipathy towards Wells' work, which, for obvious reasons, does not register in their brief correspondence. Key is this distinction between the romantic and scientific, and it is Read's embrace of the romantic that informed his openness to a spiritual dimension in anarchist politics that would have been an anathema to a rationalist like Wells. Despite his position in the advanced guard of modernism, Read continued to insist upon his credentials as a son of the soil. "In spite of

I8 Morris' book did, after all, bear the subtitle "being some chapters from a Utopian Romance”. William Morris, News from Nowhere or an Epoch of Rest in News from Nowhere and Other Writings, ed. Clive Wilmer (London: Penguin, I993), pp. 4I-228 (p. 4I). See also: Ruth Kinna, William Morris: The Art of Socialism (Cardiff: University of Wales Press, 2000), pp. 38-40.

19 Ruth Levitas, Utopia as Method: The Imaginary Reconstitution of Society (Basingstoke: Palgrave Macmillan, 20I3), pp. 65, 8I.

${ }_{20}$ Wells, Shape of Things to Come, pp. 22-32. 
my intellectual pretensions", he wrote in Poetry and Anarchism (1938), one of his earliest political pronouncements,

I am by birth and tradition a peasant. I remain essentially a peasant. I despise this foul industrial epoch - not only the plutocracy which it has raised to power, but also the industrial proletariat which it has drained from the land and proliferated in hovels of indifferent brick. ${ }^{21}$

Politicised in part by reading the blended aesthetic and social critique of Morris and John Ruskin, and by the poverty and ugliness he discerned in pre-First World War Halifax, Read's anarchism would reflect these influences. ${ }^{22}$ Believing that the diversity of artistic creativity was an "index" of social progress, and that modernist design, sensitive to the demands and requirements of local communities, could moderate the brutality of industrial capitalism, Read looked askance at the technocratic impulse that characterized scientifically-minded utopians such as Wells. ${ }^{23}$ Striving to fuse the design-and-planning-led urge of modernism, with the localism and direct-democracy of the organic community, Read's was a vision defined against Wells' all-seeing "world state" in which progress was secured by the actions of a technocratic elite.

These diverging perspectives came to the fore in Read's and Wells' brief correspondence. Despite his lack of sympathy for much of Wells' political vision, Read was evidently amused by The Happy Turning. A phantasmagoric and playful text in comparison to Wells' other utopian works, the cluster of stories that comprised it, including one where Wells meets Jesus, who laments the perversions of his teachings with the admonition "Never have disciples", were no doubt a relief from the oppressive internatio-

${ }^{21}$ Herbert Read, Poetry and Anarchism (London: Freedom Press, [I938] I947), p. 8.

${ }^{22}$ For more on this, see: Matthew S. Adams, 'To Hell with Culture: Fascism, Rhetoric, and the War for Democracy', Anarchist Studies 23: 2 (201 5), pp. I 8-37.

${ }_{23}$ Herbert Read, 'Preface' to To Hell With Culture (London: Routledge, I963), pp. ix-xii (p. xii). For this see also: Adams, Kropotkin, Read, and the Intellectual History of British Anarchism. 
nal situation in I943. ${ }^{24}$ But Read noted that he "enjoyed it as a story and I fully agreed with its underlying moral", concluding with the subtly ambiguous statement that "I find your fantasy as stimulating as ever". ${ }^{25} \mathrm{He}$ did have reservations, however. $\mathrm{He}$ did not mind what Wells described as the gentle "blasphemy" of the text, but saw the more virulent denunciations of religion as anachronistic. ${ }^{26}$ Religion, Read argued, posed an insignificant obstacle to social regeneration, adding laconically that it "will automatically be cleaned up as we rebuild". ${ }^{27}$ This was a mild rebuke, but it was underpinned by Read's divergence from Wells' more rigid brand of politics. Invoking Lord Acton, he made a plea for the value of both diversity and permissiveness in the face of dehumanising dogmatism:

But generally - and this, if anything, is what might divide us - I am all for Tolerance rather than Tidiness. I don't believe that good and evil determine human institutions: there is good and evil in every human institution, whether the College of Cardinals or the House of Commons, the Kremlin or the White House. Acton (whom I've been looking into lately - what a wise man) wrote: "Good and evil lie close together. Seek no artistic unity in character" - a good motto for a novelist as well as for an historian. ${ }^{28}$

For all that Read confessed to a real affinity with Wells' work, this motto pointed in a different direction. Rejecting the "tidiness" of completeness, this was an idea whose truth, Read felt, was more apparent in his own anarchist politics than in Wells' utopianism. The just society, he reflected elsewhere, was the one that truly protected and nurtured meaningful individuality and rested comfortably in its imperfection and incompleteness. "The only idea of a society which is capable of guaranteeing the integrity of the person", Read once argued, "is the negation of the idea of society." Rather than pointing to a kind of Stirnerian solipsism, for Read this reflected the fact that the "whole of what we mean by

\footnotetext{
${ }_{24}$ Wells, The Happy Turning, p. I4.

${ }_{25}$ Read to Wells: 27.8.43

26 Wells, The Happy Turning, p. 6.

${ }_{27}$ Read to Wells: $27^{\text {th }}$ August, I943.

${ }_{28}$ Read to Wells: $27^{\text {th }}$ August, I943.
} 
civilization or culture has been built up by a dialectical process", and, accordingly, "every advance towards community must be countered by an affirmation of individual freedom". ${ }^{29}$ There was no place, in this vision, for either an all-powerful state or the idea that a utopian society was an end in itself, a resolution of humanity's troubled history.

A month before they debated the importance of anticlericalism, Read offered Wells a more substantial overview of his politics. Seeking opinions on a series of letters that Wells had written for The Times pondering the Allies' war-aims, Read proposed a number of amendments to what would eventually appear as the pamphlet The Rights of Man, or What are We Fighting For? $3^{\circ}$ In suggesting textual improvements, Read drew heavily on the conceptual resources of his anarchist politics. "You have removed my particular bogey, the suggestion of a centralised world state with all the obsolete machinery of representative government", but Read suggested two further clauses, one addressing "consumer interests" in "some sort of guild organisation of industry", and the other calling for the abolition of that "mental dinosaur", money. Read also suggested adding a further substantive clause, the "right to membership of a community". He defined this community, in typically anarchic terms, as the ideal crucible for individual growth:

A community is an association of like-minded people for mutual aid. Each person within a community has a right to select that place within the community most appropriate to his abilities, and the duty to contribute his due quota to the common wealth. In return the community will guarantee him the supply of all the necessaries of a happy and productive life. ${ }^{3 \mathrm{I}}$

29 Herbert Read, A Coat of Many Colours: Occasional Essays (London: Routledge, I947), 3 I7, 3 I2, 3 I7.

$3 \circ$ H.G. Wells, 'Letters to the Editor: War Aims' in The Times, $26^{\text {th }}$ September I939, pp. 4; H.G. Wells, 'Letters to the Editor: War Aims: The Rights of Man' in The Times, $25^{\text {th }}$ October I939, pp. 6; H.G. Wells, The Rights of Man, or What are We Fighting For? (Harmondsworth: Penguin, I940); H.G. Wells (ed.) The Rights of Man: an Essay in Collective Definition (Brighton: Poynings Press, I943).

${ }^{\text {I }}$ Herbert Read to H.G. Wells: $28^{\text {th }}$ July, I943, HRA: HR.HGW-7 Enclo.o2. 
Here, the differences between Read's and Wells' politics come to the fore. Against the state, he poses the constructive and organisational potential of the guilds, as well as offering a trenchant defence of the community as the locus of individual growth. Beyond this, however, he firmly identifies with that Kropotkinian shibboleth, the abolition of the wage system as the prerequisite of any libertarian society. ${ }^{2}$

A particular understanding of society - of its existential importance; of its necessary independence from an "abstraction" like the state, but also of its potential to stymie individual development - clearly ran through Read's thought. ${ }^{33}$ While dismissive of the power of religion in his comments on The Happy Turning, Read's image of community nevertheless drew heavily on ideas of spiritual union. In the series of Nietzschean aphorisms that closed his pamphlet Existentialism, Marxism and Anarchism (1949), he developed this concept of society, arguing, in terms that Wells would have struggled to recognise, that the commune was social unit best suited to preserving "the freedom of the person". ${ }^{34}$ Revealingly drawing on the work of Martin Buber, he added that successful communal experiments, while rare, were those defined by a strong and unifying religious impulse. Where they failed, Read perceived the root of this collapse not in economic pressures, but principally as the result of a lack of durable bonds between the community's members. "Religious communities like the Hutterites", he observed, are the communities with the "longest record of success", not "because of their superior skill in agriculture or their genius for planning, but simply because their members have been with one another, in real communion." ${ }_{55}$ Quoting Henrik Infield's book Co-Operative Communism at Work (I947), Read concluded that the overriding evidence was that in religious and non-religious

${ }^{2}$ For a classic definition of this position, see: Peter Kropotkin, Act for Yourselves: Articles from Freedom, ed. Nicolas Walter \& Heiner Becker (London: Freedom Press, I998), pp. I03-II3.

33 Read, A Coat of Many Colours, 3 Io.

34 Herbert Read, Existentialism, Marxism and Anarchism (London: Freedom Press, I949), p. 27.

35 Italics are Read's own. Read, Existentialism, Marxism and Anarchism, p. 28 . 
communal experiments, success was determined by the existence of a "central emotional impulse, comparable to the religious motive...[that]...is important to the success of comprehensive co-operation". ${ }^{36}$

Spiritual union was therefore essential, Read thought, and turning to the issue of equality - a principle so often in the history of utopian thinking redolent of austerity and Spartanism invested it with a spiritual dimension too. Indeed, the association of austerity with equality, he complained, was the result of a failure to appreciate the spiritual ethos of this distributive ethic, a point he made by drawing a distinction between the desire to "make all incomes equal" and "hold all things in common". ${ }^{37}$ The former, he argued, was the intention of the "average democratic socialist", going on to suggest that the "distinction between false communism and true communism" lay in this issue. Quoting the Acts of the Apostles, Read also suggested that this was a distinction familiar to "early Christian communities":

The multitude of them that believed were of one heart [...] Neither was there any of them that lacked: for as many as were possessors of lands or houses sold them, and brought the prices of the things that were sold, and laid them down at the apostles' feet: and distribution was made unto every man according as he had need..$^{8}$

While Read cleaved to the anarchist-communist tradition in demanding a community of goods ("all is for all” in Kropotkin's dictum), he challenged the rhetorical objection that this is based on a "superhuman" perception of human nature through an appeal to the "spiritual", a position in stark contrast to Kropotkin's

${ }^{36}$ Henrik Infield cited in Read, Existentialism, Marxism and Anarchism, p. 28. A useful comparison here is with Herbert Read's friend George Woodcock, whose interest in the dissenting Christian sect the Doukhobors remained a perennial interest. For more on this see George Woodcock and Ivan Avacumovic, The Doukhobors (Toronto: Oxford University Press, I968) and Matthew S. Adams \& Luke Kelly, 'George Woodcock and the Doukhobors: peasant radicalism, anarchism, and the Canadian state', Intellectual History Review 28: 3 (2018), pp. 399-423.

37 Italics are Read's own. Read, Existentialism, Marxism and Anarchism, p. 34 .

${ }^{38}$ Read, Existentialism, Marxism and Anarchism, p. 34. 
rationalism. ${ }^{39}$ Communism of this kind was not unrealistic, Read continued, because it rested on a communion that made such organic, communal societies durable in the face of outside pressures. Invoking the Hutterites, he suggested that the "libertarian conception of society as a brotherhood" that made this communism viable, had deep historical roots. "The first Hutterite colonies were founded in 1526 ", he wrote, adding, in a broadside aimed at those incapable of thinking of social life in the absence of the nation-state, that "no other social system can boast such an undeviating record of stability and self-sufficiency." ${ }^{\circ}$ The roots of this longevity lay in their perception of community, and Read returned to the idea of "communion" and "brotherhood" to describe an encompassing sense of community with a "necessary physical (sensational) basis". ${ }^{4 \mathrm{I}}$

Viewed in the context of Read's broader philosophy, this understanding of necessary spirituality comes into sharper focus, and shows why Read and Wells had such a difficult time comprehending each other in their correspondence. A central aspect of Read's thought was a belief in the importance of appreciating the intuitive, irrational, and ethereal aspects of the phenomenological world, a belief that explains his attraction to the work of Nietzsche, Georges Sorel and Henri Bergson. ${ }^{42}$ Against the rationalism of Wells' utopianism or the "piecemeal planning, practical politics" of contemporary technocrats, Read stressed the

39 Read, Existential, Marxism and Anarchism; Kropotkin, The Conquest of Bread, p. 26.

$4^{\circ}$ Read, Existentialism, Marxism and Anarchism, p. 34.

${ }^{4}$ Read, Existentialism, Marxism and Anarchism, p. 34, 36.

${ }_{42}$ Read would recognise major faults in these theorists, especially in their politics, but all three were important formative influences. His approach to Nietzsche is an illustrative example. In his autobiography, Read details his exposure to Nietzsche's ideas in "cataclysmic" terms, confessing that encountering Nietzsche at university was a conduit to "Schopenhauer, to Kant, Hegel, Hume, Pascal, Plato", and describing Nietzsche's words as a "prophetic fire" that destroyed his "Sunday-school piety and priggish morality". By wartime, this infatuation had faded, with Read observing in I9I 5 that "Nietzsche's appeal to me is largely poetical." See Read, The Contrary Experience, p. I67, I87, 203-206, 277-27' Read, The Contrary Experience, p. I65; Herbert Read, The Tenth Muse: Essays in Criticism (London: Routledge \& Kegan Paul, I957), p. I76. 
spiritually enlivening quality of an anarchism "guided by instinct rather than reason, [that is] passionate and spontaneous rather than cool and calculated." ${ }^{43}$ Such "absurdism" had a religious parallel, he noted, in that as all religions are based on a sense "of the numinous [which is] absurd, not rooted in normal experience, closed to normal channels of perception, and resistant to normal modes of expression". ${ }^{44}$ For a sociologically-minded utopian like Wells this was too unscientific, and for the practical planner inspired by modern sociology it was too fanciful: for both it offered little in addressing immediate social and economic problems. To Read's mind, in contrast, the "ideal" had an important vitalising quality that was a corrective to the 'despair [and] nihilism' of those fixated on the immediately practicable and restored the importance of the human and creative to the mechanistic utopians - in his terms, the "poeticization of all practicalities". 45

Losing sight of the irrational was, for Read, therefore, opening the door to a pernicious kind of technocratic politics. His comments on Henri Bergson's Creative Evolution (I907) offer another route into this issue. Reading Bergson's classic text, he commented, served to temporarily ease the feeling occasioned by the loss of his childhood religion, which he observed had plunged him on a path of "bleak rationalism which was not consistent with my romantic temperament." His fleeting Bergsonianism was an antidote to the "mechanistic interpretation of the universe" he was nurturing, that, while "keeping within the world of scientific fact", eschewed a "finalist" interpretation of the universe and emphasised the spontaneity at the heart of natural processes. ${ }^{46}$ All of this was a challenge to the scientific utopianism of Wells, and Read similarly condemned both historical materialism and its conceptual sibling "logical positivism". Their insensitivity to "instinctive modes of thought, of super-rational intuitions, of the aesthetic nature of perception", leaves its theorists "slaves to their formulae - hard, intolerant, and sadistic." ${ }^{47}$ His vituperation may

\footnotetext{
43 Read, Anarchy and Order, I3, I7.

44 Read, Anarchy and Order, I3.

45 Read, Anarchy and Order, 20, I9, 23.

${ }^{46}$ Read, The Contrary Experience, p. 277, 278.

47 Read, Existentialism, Marxism and Anarchism, p. 29, 30.
} 
overstate the case, but its purpose was to stress the importance of the numinous against the "arid" instincts of modern philosophy. ${ }^{8}$ A revitalised social world, one defined by communalism and economic communism must be sensitive to the emotional and intuitive, and recognise the importance of a unity drawing its strength from something other than instrumental logic. This, in Read's view, was to appreciate the contradictions of experience, and to realise that "wisdom [...] is the needle which comes to rest between reason and romanticism". ${ }^{49}$ A modern utopia must recognise this to achieve meaningful emancipation, or the shape of things to come could only be a worsening of the noxious present.

\section{II. "In the beginning was the image": art in history 50}

Read's notion of "communion" as a foundation of a vibrant society also manifested itself in his aesthetic theory. Given his lifelong interest in the visual arts, and persistent anxiety over their social position, this was a fitting fusion. He often commented on this essential unity in his philosophy, noting in the collection of his political essays Anarchy \& Order (I954) that there was "no categorical separation [...] between what I have written on...[anarchism]...and what I have written on social problems generally [...] or on the social aspects of art." " ${ }^{\text {I }}$ Despite the renewed interest in Read's political ideas of late, and the acknowledgement that his anarchism perhaps ran deeper than has been thought, his aesthetic philosophy has not been suitably integrated with his politics. ${ }^{52}$ Looking at his histories

$4^{8}$ Read, Existentialism, Marxism and Anarchism, p. 30.

49 Read, Existentialism, Marxism and Anarchism, p. 30.

5० Herbert Read, Icon \& Idea: The Function of Art in the Development of Human Consciousness (New York: Schocken, I965), p. 88.

${ }^{5}$ Read, Anarchy and Order, p. 9.

$5^{2}$ Amongst the work on Read, Goodway has done most to rescue Read's political thought from oblivion. While he suggests that there is overlap between his politics and aesthetics, he is generally sceptical that his anarchism informed his aesthetic philosophy. See: Goodway, Anarchist Seeds Beneath the Snow; Goodway, 'Herbert Read, organicism, abstraction and an anarchist aesthetic' in Anarchist Studies. A number of other works have traced stronger connections between his aesthetics and politics, but these have tended to be relatively brief. See: Allan Antliff, 'Open form and the anarchist imperative: Herbert Read and contemporary anarchist art' in 
of aesthetics, and his vision of community as the crucible of great art, supports the view that Read's politics were a continual source of inspiration for his wider cultural theory. Moreover, Read's understanding of the sort of historical social structures that allowed past cultures to achieve artistic greatness displays an overlooked debt to late nineteenth-century socialism, particularly in the context of his more challenging works on aesthetic philosophy dating from the I950s. Like Read, Kropotkin believed that Renaissance art drew its strength from the power of a communal identity supposedly pervasive in the city-states, and his image of the Greek sculptor chiseling to "express the spirit and heart of the city", parallels Read's approach to modern European cultural history. ${ }^{53}$ Read gathered these ideas from more sources than Kropotkin alone - after all, Kropotkin was working in a characteristically socialist furrow, one also ploughed by Henry Hyndman, William Morris and Thorold Rogers - but it was a reading of Kropotkin in particular that informed Read's work. ${ }^{54}$

In one sense, Read's art theory seems ahistorical. His oft-repeated assertion that the artistic urge was a perennial and inherent aspect of the human condition, does not necessarily lend itself to nuanced historical analysis. As he reflected in I95 I: "There is no phase of art from the Palaeolithic cave-paintings to the latest developments of constructivism, that does not seem to me to be an illustration of the biological and teleological significance of the aesthetic activity

Anarchist Studies, I6: I (20I I), pp. 6-I9; Allan Antliff, 'David Goodway critiques Herbert Read' in Anarchist Studies, Vol. I9, No. I (2011), pp. 98-I06; Carissa Honeywell, A British Anarchist Tradition: Herbert Read, Alex Comfort and Colin Ward (London: Continuum, 20I I); Dana Ward, 'Art and Anarchy: Herbert Read's Aesthetic Politics' in Re-Reading Read: New Views on Herbert, ed. Michael Paraskos, (London: Freedom Press, 2007), pp. 20-33. For works on anarchism in which Read is mentioned, but analysis of his thought is comparatively underdeveloped, see: April Carter, The Political Theory of Anarchism (London: Routledge \& Kegan Paul, 197I), pp. 9I-3; Benjamin Franks, Rebel Alliances: The Means and Ends of Contemporary British Anarchisms (Edinburgh: AK Press, 2006), p. 52; Marshall, Demanding the Impossible, pp. 587-593; David Miller, Anarchism (London, J.M. Dent, I984), pp. I4I-I 5 I.

53 Kropotkin, The Conquest of Bread, p. I39.

${ }^{54}$ A. Dwight Culler, The Victorian Mirror of History (New Haven: Yale University Press, I985), p. I 55. 
in man". ${ }^{55}$ While deeming art the product of a constant aesthetic desire might entail a static interpretation of the history of art, Read was, in fact, at pains to show that art was, nevertheless, an area of constant innovation. "My whole reading of the history of art", he added in the same work, "tells me that change is the condition of art remaining art". ${ }^{6}$ In seeking to understand this change, Read was equally adamant that any overly "materialistic" explanation, shorthand for the Marxist art critics that were prominent in British art criticism in the I930s and I940s, was insufficient. ${ }^{57}$ Despite his claims for the universality of the aesthetic sensibility therefore, Read was fully committed to an historical interpretation of art that was sensitive to the impact of social and cultural change. In one the earliest expressions of this nascent aesthetic philosophy Art and Society (I936), a work that was reprinted in I967 with a fresh preface from Read defending its central assertions, he called for an understanding of art that was attuned to the role of material factors but also cognisant of art's relative autonomy:

Art $[\ldots]$ is [...] influenced like all our activities by the material conditions of existence, but as a mode of knowledge at once its own reality and its own end. It has necessary relations with politics, religion, and with all other modes of reacting to our human destiny. But as a mode of reaction it is distinct and contributes in its own right to that process of integrations which we call a civilization or a culture..$^{8}$

In cautiously trying to move the debate away from viewing art as an "efflux" of material conditions, Read was challenging the Marxist orthodoxy in art criticism, but also making the case for an historically-attuned idealistic theory of art. 59 This reading of art history was at the fore of his 1954 work Icon \& Idea, which

${ }^{55}$ Herbert Read, 'Preface [I95I]' to The Philosophy of Modern Art: Collected Essays (London: Faber and Faber, 1954), p. I3.

${ }^{56}$ Read, The Philosophy of Modern Art, p. 57

57 Read, Icon \& Idea, p. 2I. For a riposte from Read to these critics, including Alick West, see: Read, Coat of Many Colours, pp. 2I 2-22I.

${ }_{58}^{8}$ Herbert Read, Art and Society (London: Faber \& Faber, I967), p. 2.

59 Karl Marx and Frederick Engels, The German Ideology, ed. C.J. Arthur (London: Lawrence and Wishart, I999), p. 47. 
argued that art was an existentially vital source of meaning, and had even contributed to humanity's evolutionary survival:

Art [...] was never [...] an attempt to represent the totality of appearances; but rather it has been the piecemeal recognition and patient fixation of what is significant in human experience. The artistic activity might therefore be described as a crystallization, from the amorphous realm of feeling, of forms that are significant and symbolic. ${ }^{\circ}$

In a letter to the poet Stephen Spender, Read offered a pithier précis of Icon \& Idea:

The whole argument of my Harvard Lectures [...] is that society owes everything to the artist - that the philosophy and science of any age is but a commentary on its art. And even its religion religion as a commentary on instinctive ritual, on magical objects and events. The poet is a legislator, not in the sense that he lays down laws, but because he creates the pattern of ideas and 'endows' society with thought. ${ }^{6 \mathrm{I}}$

Art is at the fore of human development, and as well as underpinning our intellectual advances, offers an avenue into what lies beyond conscious thought - the realm of feeling, with its rich, suggestive, and vital symbolism.

The dualism that Read saw at the heart of artistic activity, at once eternal and individual but also shaped by context and eminently social, points to a productive tension in his thought. But his understanding of communion as the foundation of a healthy social compact, and his abiding interest in the relationship between the artist and society, clearly highlights an important historical dimension to his complex aesthetic theory. Here, as much as in his comments on the unconscious and symbolic component behind artistic inspiration, we see the significance of the spiritual to the position he reached, an idea that comes to the fore in his discussion of the Renaissance. Artistically, Read was often rather ambivalent towards the achievements of the Renaissance,

\footnotetext{
60 Read, Icon \& Idea, p. I 8.

${ }^{61}$ Herbert Read to Stephen Spender: $22^{\text {nd }}$ February, I955, HRA, 49/28/ I-HR/SS-70 Enclo.oI2.
} 
but thought that its enduring cultural impact, acting parallel with the philosophical triumphs of the age, was a result of a general emancipation from the "central imperial power [of] the Church". ${ }^{62}$ In freeing itself from the requirement of "illustrating" religious "dogma" that cramped the creativity of medieval art, the Renaissance began with a loosening of these binds and a growing interest in "natural phenomena" and a "reaffirmation of classical humanism". ${ }^{63}$ Mirroring Kropotkin's view of the rise of the city-states and the communal movement in twelfth-century Europe, Read argued that this cultural change emerged from a complex of economic and social factors. Following Kropotkin's argument in Mutual Aid, he suggested that with the eclipse of the Church's authority, social life was diversified and invigorated. ${ }^{64}$ "Here a republic challenged the authority of the Pope", he wrote,

Elsewhere a king disposed the [...] monasteries [...] events which loom large in our history books. More significant, however, is the change in mood and temperament which affected people at large. The actual process consisted, I believe, of an infinite series of small deflections and counter-deflections caused first by one force and then [...] another, the heart taking, as a result, the zig-zag course of a vessel tacking against the wind. As the historical process developed, it revealed itself as a disintegration, better still, as differentiation. ${ }^{65}$

The power of Renaissance humanism grew from this freedom, as, in Read's view, the artist won the space to express "his sensibility", rather than being required to glorify God, and in turn could reflect on the relationship between the individual and society. "The artist declared himself, confessed his humanity", Read wrote, "and celebrated the humanity of his fellow-men". ${ }^{66}$

Read was not arguing that turning the clock back was either possible or desirable. He chastised William Morris for his naive commitment to medievalism, and criticised his failure to recognise

${ }_{62}$ Read, Art and Society, p. 67. On his ambiguous relation to the Renaissance, consider: Read, A Coat of Many Colours, pp. I-5.

${ }_{63}$ Read, Icon \& Idea, p. 93.

${ }^{64}$ For Kropotkin's narrative, see: P. Kropotkin, Mutual Aid: A Factor of Evolution (London: Penguin, [I90I] I939), pp. I29-I79.

${ }_{65}$ Read, Art and Society, p. 67

${ }^{66}$ Read, Art and Society, p. 67. 
the potential for machinery to produce aesthetically beautiful artefacts. ${ }^{67}$ Neither was Read blind to the iniquities of the patronage system that underpinned this period of artistic creativity. In Art and Society, for example, he noted that the Renaissance often offered a "specious" freedom, one that might leave the artist "free to express himself, but only on condition that the "self" expressed was a marketable commodity". ${ }^{68}$ Also, Read cautioned against seeing the Renaissance as a united phenomenon, noting the existence of a "Northern Renaissance" operating under the influence of the Reformation, and a "southern Renaissance" pursuing its own unique path, with the latter offering a secularized, "positive process [...] in the direction of increasing self-assertion, self-affirmation, self-control", and a subsequent reorientation of art. ${ }^{69}$ But Read's interest in the social aspect of the Renaissance rested on a belief that it approximated the notion of communion he explored in his political writings, and despite his qualifications, he associated the Italian experience of the Renaissance as an epitome of this spiritual communion. Echoing characteristically anarchist concerns over the size of decision-making units, he noted that the "integrated communities of the past - Athens, Etruria, the Christian communities of the Middle Ages, Venice in its republican glory - [...] were never large", and their working democratic principles, even if they were "sometimes [...] careless of civil liberties", allowed art to grow. More than this, Read concluded that the pervasive mutual aid ethic existing in these communities nurtured a spiritual unity with direct cultural consequences:

They were not conscious of the artist as a separate [...] kind of man. They were only conscious of a living community, its members differentiated according to their individual skills, and all contributing to the common glory. ${ }^{70}$

${ }^{67}$ Read did note that Morris reached some accommodation with the machine later in life Read, Poetry and Anarchism, 9; Herbert Read, Art and Industry (London: Faber and Faber, I934 [I944]), 39-47.

68 Read, Art and Society, 65

69 Read, Art and Society, p. 66.

${ }^{70}$ This aphorism can be found in the extended version of 'Chains of Freedom', published in Anarchy and Order. See: Read, Anarchy and Order, p. 222. 
From this imperfect communion, the imperfect art of the Renaissance grew.

Read was evidently not glorifying the role of Christianity in a conventional sense. While recognizing the realities of aristocratic patronage and the imprimatur of the Church as forces shaping Renaissance art, he also emphasised the idea that its grandeur grew from a social soil fertilised by the freedom and unity of the communal movement. The spiritual - however attenuated by competing forces - was nevertheless essential. Writing in a different context, Read noted that while the achievements of modern science had made the "supernatural" sanction of religion obsolete, that obviously did not mean that the "state of our scientific knowledge is final or absolute". Rather than religious obscurantism or Zamyatinian rationalism, the solution to social stability lay instead somewhere between these poles:

No one who has given the least thought to the morphology of societies will be disposed to deny that they always depend for their cohesion and survival upon some unifying idea, which unifying idea has generally been of a mystical or religious kind. Only the most inveterate rationalist would be hardy enough to believe that a society might exist on a purely rational basis [...] I do not estimate the survival value of such a society very highly - it would probably die of a kind of communal accidie. ${ }^{7 \mathrm{I}}$

Read's art histories give an indication of how he saw communion in action, and reveal how this spiritual ethos stemmed from his perception of mutual aid as a logic of group organisation. Although working in a seam of thought inaugurated by Kropotkin, and coupling his ideas to Kropotkin's, Read's emphasis on the emotional aspect of mutual aid betrays a subtler conception of this principle. Kropotkin was not silent on the emotional quality of mutual aid, after all, both Ethics (I92I) and shorter pieces such as the pamphlet Anarchist Morality (I 892) dwell on "large natures overflowing with tenderness, with intelligence, with goodwill", but his motivating desire was to root this ethical language in the discourse of

${ }^{71}$ Read, A Coat of Many Colours, 3 I 4, 3 I 5. 
nineteenth-century science. ${ }^{72}$ Anarchism was a moral denunciation of capitalism, but one apparently backed up by the weight of the latest scientific thinking. Read largely accepted this position, tellingly observing that Kropotkin had adduced impressive "empirical evidence" to justify the theory of mutual aid, but deliberately eschewed the language of positivism, fearful that it would open the door to the emotionally withered politics of a utopian like Wells. ${ }^{73}$ Indeed, in The Philosophy of Anarchism ( 1940 ), while lambasting Marxism for its premature rejection of religious feeling, Read confessed that although he had "no religion to recommend and none to believe in [...] on the evidence of [...] history [...] a religion is a necessary element in any organic society." ${ }^{74}$ And, he tied the idea of spiritual ecstasy to aesthetic pleasure, arguing that "poetry, in its intensest and most creative moments, penetrates to the same level of the unconscious as mysticism." This sibling relationship led Read to ponder if the "origins of a new religion", one congruent with anarchist principles, might be found "if not in mysticism, then in art." 75 Wherever it was to come from, a reassessment of the spiritual would define anarchist society, and the effervescent cultural creativity and experimentation that would come with it.

\section{Locating Read}

Read's sympathy towards spiritual expressions, and his belief that any future anarchist society must be united by some kind of spiritual ethos, shows that he was engaged in a creative reading of the historical tradition of anarchism, notably Kropotkin's work. His cultural politics was not a simple reapplication of Kropotkin's ideas to meet the challenges of contemporary political life, but a significant revision of these political principles in a quest to maintain the relevance of anarchism in a very different world. This revision bore the imprint of both Read's particular interests (art

${ }^{72}$ Peter Kropotkin, 'Anarchist Morality' in Fugitive Writings, ed. George Woodcock (Montreal: Black Rose Books, [I 892] I993), pp. I 27-I 53.

73 Read, A Coat of Many Colours, p .63

74 Herbert Read, The Philosophy of Anarchism (London: Freedom Press, I940), p. 25.

75 Read, Philosophy of Anarchism, p. 26 
and cultural creativity), but also a broader intellectual climate in which coming to terms with the legacy of the First World War was, for obvious reasons, a key concern. Read, who had served on the western front with distinction and found his initial notoriety as a war poet, was a characteristic representative of this tradition, and the Great War remained a perpetual frame of reference in his writing. Indeed, in the year before his death, Read tied his conversion to anarchism directly to his experience of war, observing that the "fidelity" of comradeship that emerged in the heat of battle, was a pellucid lesson to him in the instinctual nature of mutual aid. ${ }^{76}$ The war was also a time of intellectual growth for Read, who, his education interrupted by mobilisation, avidly digested the pamphlet literature of nineteenth-century socialism and the latest modernist periodicals including A.R. Orage's The New Age and Dora Marden's The Egoist, both of which would later be vehicles for Read's literary work. His idiosyncratic modernism developed in this context, his initial enthusiasm for the semantic discipline and clarity of Imagist poetry ultimately tempered by his enduring interest in the defining characteristics of romanticism: emotion, expression, and a fascination with nature.

Read's politics emerged from this complex of ideas: obsessed with the importance of artistic self-expression and built upon an appeal to the spiritual, whilst at the same time accommodating itself to the rationalistic discourse of nineteenth-century anarchism. Inevitably this entailed tensions, but Read's navigation of these competing values - his efforts to strike a balance between "reason and romanticism" that informed a particular vision of modernist art - should also be recognised as the product of its time. ${ }^{77}$ With his championing of modernism in mind, a contribution

${ }^{76}$ Herbert Read, The Cult of Sincerity (London: Faber \& Faber, I968), p. 4I. For more on these themes, see: Matthew S. Adams, 'Herbert Read and the Fluid Memory of the First World War', Historical Research, 88: 240, pp. 333-354; Matthew S. Adams, 'Mutualism in the Trenches: Anarchism, Militarism and the Lessons of the First World War' in Adams \& Ruth Kinna (eds.) Anarchism, I9I4-I8: Internationalism, Anti-Militarism, and War (Manchester: Manchester University Press, 20I7), pp. 243-262.

77 Tellingly, this was the title of Read's first collection of essays. Herbert Read, Reason and Romanticism: Essays in Literary Criticism (London: Faber and Gwyer, I926). 
that has only recently been rescued from historical oblivion, ${ }^{78}$ the First World War figures prominently in efforts to understand the growth of this cultural stance. One approach is to see the war, in undermining the verities of the Victorian and Edwardian age, as a crucial moment; its jarring and destabilising effects giving rise to new types of poetic diction and artistic imagery that reflected the scale of the trauma. What Graham Greene once referred to as the "Victorian look of confidence, of being at home in the world and knowing the way round", was superseded by a post-war cynicism, whose emergence one scholar boldly dated to the first day of the Somme, $\mathrm{I}^{\text {st }}$ July, I9 I $6 .{ }^{79}$ Modernism was the artistic articulation of this mentality, matched in the hedonistic behaviour of the "younger generation" in the I920s, who met with scepticism "the moralistic idealism that had kept busy the slaughterhouse that was the Western Front". ${ }^{80}$

While the First World War may have been a catalyst for modernism in the arts, it would be reductive to see this cultural growth purely in terms of the rupturing effects of war. Indeed, as Read was well aware, modernism had deeper roots, as he playfully observed when arguing that "modern art" was born in the immediate aftermath of the "Universal Exhibition of 1889 " ${ }^{8 \mathrm{I}}$ Here, he wrote, the displays of "primitive art" intoxicated Gauguin and Van Gogh, forcing them to see a connection across the ages that unmasked the importance of social unrest and "insecurity" on the movement "away from representational realism [...] towards some degree of abstraction or symbolism". ${ }^{82}$ Not only was modernism in the arts frequently informed by a renewed contact with tradition then, but in the aftermath of war people often looked back, rather than for-

${ }^{78}$ Michael Paraskos, 'The Curse of King Bomba: Or How Marxism Stole Modernism' in Paraskos (ed.) Rereading Read: New Views on Herbert Read (London: Freedom Press, 2007), pp. 44-57; Jerald Zaslove, 'Herbert Read and Essential Modernism: Or the Loss of an Image of the World' in David Goodway (ed.) Herbert Read Reassessed (Liverpool: Liverpool University Press, I998), pp. 287-308.

79 Graham Greene, The End of the Affair (London, (I95I) 2004), p. I4; Paul Fussell, The Great War and Modern Memory (London, I975), p. 29.

$8 \circ$ Eksteins, Rites of Spring, p. 258.

${ }^{81}$ Read, The Tenth Muse, p. 304.

${ }^{82}$ Read, The Tenth Muse, p. 304, 309, 308. 
ward: in mourning, an idealised past was more of a balm than the queasy disruptions of challenging modernism. ${ }^{83}$

Again, Read's own work, in spite of his perceived position as the "last modern", shows this process at work. ${ }^{84}$ In the article "The Greatest Work of Art in the World", he recounts a visit Florence on the eve of war in July I939. With the city pregnant with anticipation at the impending conflict, Read admitted that his "systematic tour of churches and museums, palaces and picture galleries" provided distraction but little satisfaction, until, returning to the Museo Archeologico, he encountered a "small object I had never seen before [...] unlabelled and unhonoured." ${ }^{5}$ This bronze - "the head of a negro boy, probably a slave" - affected Read more deeply than the treasure troves of "High Renaissance" artefacts. As he wrote:

Whatever he was, and whenever he lived, this artist created something without age or epoch, something so elementally simple and fresh that it had the power, in my sophisticated mind, to rouse the highest pleasure and to prompt - as an aftermath - the deepest questionings.

Read over-dramatised this event, but his point was to emphasise the ability of the forgotten craftsman to create an object whose beauty could survive the ages, and sit happily alongside the canonical works of the Renaissance. This democratic vision informed his aesthetic politics, but also demonstrates the retrospective aspect of modernism at work. Rather than emancipation from history, modernists like Read were involved in a creative discussion with the past, and the artistic departures of modernism often gained their impetus from a contact with tradition instead of its renunciation. Read's panegyric for the bronze in a dusty Florentine cabinet was an expression of this idea, and, aside from an invitation to think more openly about the criterion of beauty, shows that it is more useful to see modernism in a history of continuity, rather than rupture.

${ }^{83}$ Jay Winter, Sites of Memory, Sites of Mourning: The Great War in European Cultural History (Cambridge: Cambridge University Press, I995).

${ }^{8}$ King, The Last Modern.

${ }^{85}$ Read, A Coat of Many Colours, p. I, 2. 
Placed in this intellectual context, Read's position on anarchist spirituality becomes clearer. Although he continued to frame both his politics and aesthetics as a product of logic, and saw the essential truth of these theories increasingly revealed by modern science, he equally strove to strike a balance with a sense of the numinous. Concluding The Contrary Experience, following a protracted reflection on how the work of the naturalist D'Arcy Thompson and the philosopher Alfred North Whitehead echoed his belief that the laws of art were akin to the laws of nature, Read noted that this language of logic was always tempered in his mind by a fascination with the unknowable:

In this story of the growth of my mind, every advance has been due to the exercise of the faculty of reason; but that advance is not uniform, unimpeded. It abounds in deviations and contradictions: the opposed terms of a dialectical progression. The very bases of reason, the perceptions of an unclouded intellect, are continually [...] contradicted by the creative fictions of the imagination, by a world of illusion no less real than the reality of our quick awareness. ${ }^{86}$

His temporising over the importance of reason versus intuition may make Read's philosophical voice a difficult one to comprehend, but this search for a compromise bears the imprint of a thinker working in an age seeking to come to terms with an unprecedented cataclysm. Just as the spiritual more generally was to undergo something of a renewal in the aftermath of war, so it is possible to read Read's spirituality as a product of the rejection of an essentially Victorian rationalism that impelled Europe on the path to war. ${ }^{87}$ Faith in progress and the boons promised by science, and, importantly, the conquering of political life by adventurous social scientists keen to reshape society in accordance with their observations and measurements, left Read cold. He may have criticised Wells for wasting too much energy ridiculing a Church that was already bankrupt, but underlying this was a belief that the more positive aspects of spiritual communion had

\footnotetext{
${ }^{86}$ Read, The Contrary Experience, p. 346, 353.

${ }^{87}$ Winter, Sites of Memory, Sites of Mourning, pp. 54-77; Jennifer Hazelgrove, 'Spiritualism after the Great War' in Twentieth Century British History, Io: 4 (I999), pp. 404-430.
} 
also been neglected by social thinkers too intent on unmasking the laws that governed society. Mutual aid, Read wrote, might be a demonstrable fact by turning to "biology and history", but if anarchists lost the "mystique" of this theory they were following a road tramped by positivists and dialectical materialists decades earlier. Their faith in the powers of logic led to the "pretentious" belief that from the "incomplete record of past events" it was possible to deduce a "law of history", which in turn led to the willing application of force to achieve these apparently predestined ends. To lose sight of the unknowable was a mistake. ${ }^{88}$

\section{Conclusion}

Read was not a religious thinker, and distrusted the claims of organised religion. His understanding of spirituality was, in this sense, functional ${ }^{89}$, and its importance rested in its ability to provide communities with strong social bonds, and thereby support a vibrant artistic culture. This rested on a particular sense of the spiritual. It was not defined by a "relationship with a Transcendent Being”, but it certainly did point to practices and habits "informed by a certain spiritual tradition, which fosters a sense of meaning, purpose, and mission in life".${ }^{90}$ It was the promise of a sense of unity and commitment to a common purpose that this revealed that attracted Read, and in railing against a culture that he increasingly saw as moribund, he became interested in the integrative value of spirituality. His was thus not an unqualified acceptance of religion, and Read clung to an interpretation of organised religion that would have been familiar to atheistic nineteenth-century socialists. But in adding a sense of the spiritual to the theory of mutual aid, Read made a significant, and historically revealing, contribution to anarchist thought. While heavily indebted to Kropotkin, the scientistic air of nineteen-century anarchism did not appeal to Read's artistic temperament. In the process of upholding Kropotkin's key ideas - clear in his defence of mutual aid

\footnotetext{
${ }^{88}$ Read, The Tenth Muse, p. 96.

${ }^{89} \mathrm{I}$ am indebted to Alexandre Christoyannopoulos for this point.

$9 \circ$ David R. Hodge, 'Spirituality: Towards a Theoretical Framework', Social Thought, I9: 4 (2000), pp. I-20 (p. 2)
} 
as a scientifically sound theory - Read nevertheless tried to soften its potentially unforgiving rationalism with a dose of spirituality; a tonic that was also a reminder, in the post-war context, of the dangers of scientific hubris and tidy social thinking.

It was perhaps with a hint of regret that Read confessed that he could never become a "believer" in a simple sense. "And so we come to the spiritual void that opens in my own path", he wrote, shortly before his death in I968:

I have read Berdyaev and many other Christian apologists, and have been moved especially by two of them, Kierkegaard and Simone Weil [...] The difficulty I experience with all such Christian apologists is that they rely, for their final argument, on the necessity of grace. $^{9 \mathrm{r}}$

Yet, on the next page, Read willingly appropriated the language of theology to insist on the pressing need for radical change. "The present and urgent necessity", he argued, "is to admit the sickness of man's soul and take practical measures to cure it." 92 While Read clearly lacked any conventional religious faith, it is also apparent that his anarchism was invested with a deep sense of spirituality. Looking forward to an anarchist society in which rich aesthetic sensibility was universal, Read understood art as enabling an existential reflection on the nature of human life, and granting access to the deeper issues of human existence. In short, art would enthuse humanity, understood in the original meaning of the word enthous - "possessed by a god". The conflict between the rational and intuitive was not something Read could solve, and neither did he intend to, rather these poles created a magnetic field that pulsed through his aesthetic politics. And Read was well aware of his equivocation. Examining whether a personal relationship with an idea of God in the manner of Martin Buber or Carl Jung was the solution, he confessed that he had left the permutations of philosophical spirituality frustratingly unexplored, something, he added, that might mask his own lack of conviction.

${ }^{91}$ Read, The Cult of Sincerity, p. 47.

92 Read, The Cult of Sincerity, p. 48 . 
"I seem to avoid the final issue", he concluded, "perhaps [I] have done so all my life." ${ }_{93}$

\section{References}

Adams, Matthew S. \& Luke Kelly, 'George Woodcock and the Doukhobors: peasant radicalism, anarchism, and the Canadian state', Intellectual History Review 28: 3 (2018), pp. 399-423.

Adams, Matthew S. 'Mutualism in the Trenches: Anarchism, Militarism and the Lessons of the First World War' in Adams \& Ruth Kinna (eds.) Anarchism, I9I4-I8: Internationalism, Anti-Militarism, and War (Manchester: Manchester University Press, 2017), pp. 243-262.

Adams, Matthew S. 'To Hell with Culture: Fascism, Rhetoric, and the War for Democracy', Anarchist Studies, 23: 2 (201 5) pp. I 8-37.

Adams, Matthew S. Kropotkin, Read, and the Intellectual History of British Anarchism: Between Reason and Romanticism (Basingstoke: Palgrave, 20I 5 ).

Adams, Matthew S. 'Herbert Read and the Fluid Memory of the First World War', Historical Research, 88: 240 (201 5), pp. 333-354.

Antliff, Allan. 'Open form and the anarchist imperative: Herbert Read and contemporary anarchist art' in Anarchist Studies, I6:I (20II), pp. 6-I9.

Antliff, Allan. 'David Goodway critiques Herbert Read' in Anarchist Studies, Vol. I9, No. I (201 I), pp. 98-106.

Carter, April. The Political Theory of Anarchism (London: Routledge \& Kegan Paul, I971).

Christoyannopoulos, Alexandre J.M.E. Christian Anarchism: A Political Commentary on the Gospel (Exeter: Imprint Academic, 2010).

Christoyannopoulos, Alexandre and Lara Apps. 'Anarchism and Religion' in Carl Levy \& Matthew S. Adams (eds.) The

93 Read, The Cult of Sincerity, p. 34. 
Palgrave Handbook of Anarchism (Basingstoke: Palgrave, 2019), pp. I69-I92.

Culler, A. Dwight. The Victorian Mirror of History (New Haven: Yale University Press, I985).

Dunne, J.W. An Experiment with Time (London: A. \& C. Black, I929).

Eksteins, Modris. Rites of Spring: The Great War and the Birth of the Modern Age (New York, I989).

Franks, Benjamin. Rebel Alliances: The Means and Ends of Contemporary British Anarchisms (Edinburgh: AK Press, 2006).

Fussell, Paul. The Great War and Modern Memory (London, I975).

Goodway, David. Anarchist Seeds Beneath the Snow: Left-Libertarian Thought and British Writers from William Morris to Colin Ward (Liverpool: Liverpool University Press, 2006).

Goodway, David. "Herbert Read, organicism, abstraction and an anarchist aesthetic" in Anarchist Studies, Vol. I9, No. I (200I), pp. 82-97.

Greene, Graham. The End of the Affair (London, (I95I) 2004).

Hazelgrove, Jennifer. 'Spiritualism after the Great War' in Twentieth Century British History, IO: 4 (I999), pp. 404-430.

Heelas, Paul and Linda Woodhead. The Spiritual Revolution: Why Religion is Giving Way to Spirituality (Oxford: Blackwell, 2005).

Hodge, David R. 'Spirituality: Towards a Theoretical Framework', Social Thought, I9: 4 (2000), pp. I-20.

Honeywell, Carissa. A British Anarchist Tradition: Herbert Read, Alex Comfort and Colin Ward (London: Continuum, 20I I).

King, James. The Last Modern: A Life of Herbert Read (New York: St. Martin's Press, I990).

Kinna, Ruth. William Morris: The Art of Socialism (Cardiff: University of Wales Press, 2000).

Kropotkin, Peter. Act for Yourselves: Articles from Freedom, ed. Nicolas Walter \& Heiner Becker (London: Freedom Press, I998)

Kropotkin, Peter. 'Anarchist Morality' in Fugitive Writings, ed. George Woodcock (Montreal: Black Rose Books, [1892] I993), pp. I 27-I 53 . 
Kropotkin, P., Mutual Aid: A Factor of Evolution (London: Penguin, [I90I] I939).

Kropotkin, Peter. The Conquest of Bread (New York: G.P. Putman's Sons, I907).

Levitas, Ruth. Utopia as Method: The Imaginary Reconstitution of Society (Basingstoke: Palgrave Macmillan, 2013).

Marshall, Peter. Demanding the Impossible: A History of Anarchism (London: Fontana, I993).

Marx, Karl. and Frederick Engels, The German Ideology, ed. by C.J. Arthur (London: Lawrence and Wishart, I999).

Miller, David. Anarchism (London, J.M. Dent, I984).

Morris, William. News from Nowhere or an Epoch of Rest in News from Nowhere and Other Writings, ed. by Clive Wilmer (London: Penguin, I993).

Paraskos, Michael. 'The Curse of King Bomba: Or How Marxism Stole Modernism' in Paraskos (ed.) Rereading Read: New Views on Herbert Read (London: Freedom Press, 2007), pp. 44-57.

Read, Herbert. The Cult of Sincerity (London: Faber \& Faber, I968).

Read, Herbert. Art and Society (London: Faber \& Faber, 1967).

Read, Herbert. Icon \& Idea: The Function of Art in the Development of Human Consciousness (New York: Schocken, I965).

Read, Herbert. 'Preface' to To Hell With Culture (London: Routledge, I963), pp. ix-xii (p. xii).

Read, Herbert. The Contrary Experience: Autobiographies (London: Faber and Faber, 1963)

Read, Herbert. The Tenth Muse: Essays in Criticism (London: Routledge \& Kegan Paul, I957).

Read, Herbert. Anarchy and Order: Essays in Politics (London: Faber \& Faber, 1954).

Read, Herbert. 'Preface [195I]' to The Philosophy of Modern Art: Collected Essays (London: Faber and Faber, I954), pp. I3-I4.

Read, Herbert. Existentialism, Marxism and Anarchism (London: Freedom Press, I949). 
Read, Herbert. A Coat of Many Colours: Occasional Essays (London: Routledge, I947).

Read, Herbert. Art and Industry (London: Faber and Faber, I934 [I944]).

Read, Herbert. Poetry and Anarchism (London: Freedom Press, [1938] 1947).

Read, Herbert. The Philosophy of Anarchism (London: Freedom Press, 1940).

Read, Herbert. Reason and Romanticism: Essays in Literary Criticism (London: Faber and Gwyer, I926).

Walter, Nicolas. "Anarchism and Religion" in Damned Fools in Utopia, ed. by David Goodway (Oakland, CA: PM Press, 2009), pp. $279-285$

Ward, Dana. 'Art and Anarchy: Herbert Read's Aesthetic Politics' in Re-Reading Read: New Views on Herbert, ed. by Michael Paraskos, (London: Freedom Press, 2007), pp. 20-33.

Wells, H.G. The Happy Turning: A Dream of Life (London: William Heinemann, I945).

Wells H.G. (ed.) The Rights of Man: an Essay in Collective Definition (Brighton: Poynings Press, I943).

Wells, H.G. The Rights of Man, or What are We Fighting For? (Harmondsworth: Penguin, I940).

Wells, H.G. The Shape of Things to Come (London: Gollancz, [I933] 20II).

Winter, Jay. Sites of Memory, Sites of Mourning: The Great War in European Cultural History (Cambridge: Cambridge University Press, I995).

Woodcock, George, and Ivan Avacumovic, The Doukhobors (Toronto: Oxford University Press, I968).

Zaslove, Jerald. 'Herbert Read and Essential Modernism: Or the Loss of an Image of the World' in David Goodway (ed.) Herbert Read Reassessed (Liverpool: Liverpool University Press, I998), pp. 287-308. 